A.Y. HOEKSTRA

A.K. Chapagain

JULY 2006

\section{THE WATER FOOTPRINTS OF}

MOROCCO AND

THE NetheRLANDS 



\title{
THE WATER FOOTPRINTS OF MOROCCO AND THE NETHERLANDS
}

\author{
A.Y. HOEKSTRA* \\ A.K. ChAPAGAIN \\ JULY 2006 \\ Value of Water Research Report Series No. 21 \\ * contact author: Arjen Hoekstra, a.y.hoekstra@utwente.nl
}

The Value of Water Research Report Series is published by UNESCO-IHE Institute for Water Education, Delft, the Netherlands in collaboration with

University of Twente, Enschede, the Netherlands, and Delft University of Technology, Delft, the Netherlands 



\section{Value of Water Research Report Series}

Editorial board:

Arjen Y. Hoekstra - University of Twente, a.y.hoekstra@utwente.nl

Hubert H.G. Savenije - Delft University of Technology, h.h.g.savenije@.citg.tudelft.nl

Pieter van der Zaag - UNESCO-IHE Institute for Water Education, p.vanderzaag@unesco-ihe.org

Reports are downloadable from $\underline{\text { htp: }: / / w w w . w a t e r f o o t p r i n t . o r g}$

1. Exploring methods to assess the value of water: A case study on the Zambezi basin.

A.K. Chapagain - February 2000

2. Water value flows: A case study on the Zambezi basin.

A.Y. Hoekstra, H.H.G. Savenije and A.K. Chapagain - March 2000

3. The water value-flow concept.

I.M. Seyam and A.Y. Hoekstra - December 2000

4. The value of irrigation water in Nyanyadzi smallholder irrigation scheme, Zimbabwe.

G.T. Pazvakawambwa and P. van der Zaag - January 2001

5. The economic valuation of water: Principles and methods

J.I. Agudelo - August 2001

6. The economic valuation of water for agriculture: A simple method applied to the eight Zambezi basin countries

J.I. Agudelo and A.Y. Hoekstra - August 2001

7. The value of freshwater wetlands in the Zambezi basin

I.M. Seyam, A.Y. Hoekstra, G.S. Ngabirano and H.H.G. Savenije - August 2001

8. 'Demand management' and 'Water as an economic good': Paradigms with pitfalls

H.H.G. Savenije and P. van der Zaag - October 2001

9. Why water is not an ordinary economic good

H.H.G. Savenije - October 2001

10. Calculation methods to assess the value of upstream water flows and storage as a function of downstream benefits

I.M. Seyam, A.Y. Hoekstra and H.H.G. Savenije - October 2001

11. Virtual water trade: A quantification of virtual water flows between nations in relation to international crop trade A.Y. Hoekstra and P.Q. Hung - September 2002

12. Virtual water trade: Proceedings of the international expert meeting on virtual water trade

A.Y. Hoekstra (ed.) - February 2003

13. Virtual water flows between nations in relation to trade in livestock and livestock products

A.K. Chapagain and A.Y. Hoekstra - July 2003

14. The water needed to have the Dutch drink coffee

A.K. Chapagain and A.Y. Hoekstra - August 2003

15. The water needed to have the Dutch drink tea

A.K. Chapagain and A.Y. Hoekstra - August 2003 
16. Water footprints of nations

Volume 1: Main Report, Volume 2: Appendices

A.K. Chapagain and A.Y. Hoekstra - November 2004

17. Saving water through global trade

A.K. Chapagain, A.Y. Hoekstra and H.H.G. Savenije - September 2005

18. The water footprint of cotton consumption

A.K. Chapagain, A.Y. Hoekstra, H.H.G. Savenije and R. Gautam - September 2005

19. Water as an economic good: the value of pricing and the failure of markets

P. van der Zaag and H.H.G. Savenije - July 2006

20. The global dimension of water governance: Nine reasons for global arrangements in order to cope with local water problems

A.Y. Hoekstra - July 2006

21. The water footprints of Morocco and the Netherlands

A.Y. Hoekstra and A.K. Chapagain - July 2006

22. Water's vulnerable value in Africa

P. van der Zaag - July 2006 


\section{Contents}

Summary

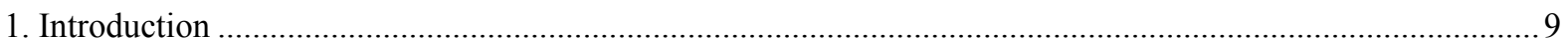

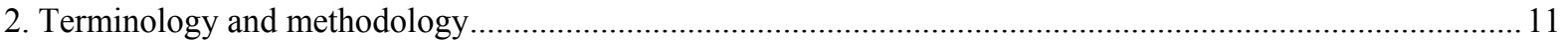

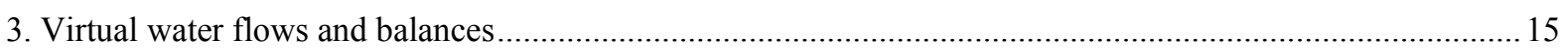

4. Agricultural water footprints of Morocco and the Netherlands ................................................................ 17

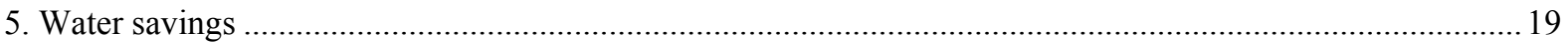

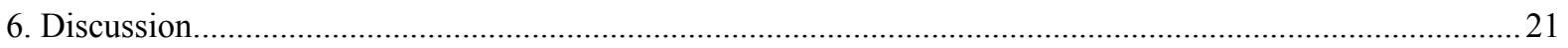

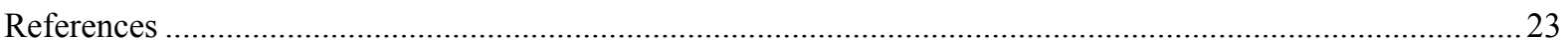

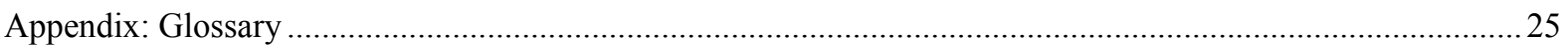





\section{Summary}

Although bulk water itself is not a tradable commodity, agricultural commodities - that generally consume a lot of water during production - are increasingly being traded. As a result, water use within a nation is no longer an appropriate indicator of national water demand, at least not if one takes the consumer's perspective. The aim of the paper is to assess the water footprints of Morocco, a semi-arid / arid country, and the Netherlands, a humid country. The water footprint of a country is defined as the volume of water needed for the production of the goods and services consumed by the inhabitants of the country. The internal water footprint is the volume of water used from domestic water resources; the external water footprint is the volume of water used in other countries to produce goods and services imported and consumed by the inhabitants of the country. The study shows that both Morocco and the Netherlands import more water in virtual form (in the form of water-intensive agricultural commodities) than they export, which makes them dependent on water resources elsewhere in the world. The water footprint calculations show that Morocco depends for $14 \%$ on water resources outside its own borders, while the Netherlands depend on foreign water resources for $95 \%$. It is shown that international trade can result in global water saving when a water-intensive commodity is traded from an area where it is produced with high water productivity to an area with lower water productivity. If Morocco had to domestically produce the products that are now imported from the Netherlands, it would require 780 million $\mathrm{m}^{3} / \mathrm{yr}$. However, the imported products from the Netherlands were actually produced with only 140 million $\mathrm{m}^{3} / \mathrm{yr}$, which implies a global water saving of 640 million $\mathrm{m}^{3} / \mathrm{yr}$. 



\section{Introduction}

Throughout the world freshwater resources have become scarcer during the past decades, due to an increase in population and economic activity and a subsequent increase in water appropriation (Postel et al., 1996; Shiklomanov, 2000; Vörösmarty et al., 2000; Vörösmarty and Sahagian, 2000). In most countries the increase in water use was largely related to increased production of agricultural products for domestic consumption. However, also water use for producing export commodities has become significant in various countries. Chapagain and Hoekstra (2004) estimate that in the period 1997-2001 about 15\% of the global water use in agriculture was not for producing commodities for domestic consumption but for export. In some specific countries (e.g. Australia, Canada, Argentina), the agricultural water use for export is even larger than for domestic consumption. These countries export water in 'virtual' form, that is in the form of agricultural commodities. The virtual water content of a commodity is the volume of water used to produce the commodity, measured at the place where the commodity was actually produced. The other side of this phenomenon is that some countries import agricultural commodities instead of producing them domestically, thus importing water in virtual form and saving domestic water resources. Examples are most countries in the Middle East, North Africa and Europe, but also South Africa, Mexico and Japan (Chapagain and Hoekstra, 2004).

The aim of this paper is to assess the water footprints of Morocco, a semi-arid / arid country, and the Netherlands, a humid country. The water footprint of a nation is the total annual volume of freshwater that is used to produce the goods and services consumed by the inhabitants of the nation. Generally, a part of the footprint of a nation falls inside the country (internal water footprint) and another part presses on other countries in the world (external water footprint). For that purpose we quantify for both countries incoming and outgoing virtual water fluxes. Besides, we estimate water savings or losses that result from the international virtual water trade. As period of analysis we have taken 1997-2001, because this was the most recent five-year period for which all necessary data could be obtained. The study is limited to agricultural commodities, since they are responsible for the major part of global water use (Postel et al., 1996). 



\section{Terminology and methodology}

The paper makes use of a number of novel concepts such as the 'virtual water content' of a commodity, the 'water footprint' of a nation and the 'water saving' as a result of international trade. The virtual water concept was introduced by Allan (1998a,b) when he studied the possibility of importing virtual water (as opposed to real water) as a partial solution to problems of water scarcity in the Middle East. Allan elaborated the idea of using virtual water import (coming along with food imports) as a tool to release the pressure on the scarcely available domestic water resources. Virtual water import thus becomes an alternative water source, next to endogenous water sources. Imported virtual water has therefore also been called 'exogenous water' (Haddadin, 2003). Global virtual water flows were first calculated by Hoekstra and Hung (2002, 2005), Zimmer and Renault (2003), Oki et al. (2003), Chapagain and Hoekstra (2004) and De Fraiture et al. (2004).

The water footprint concept has been introduced by Hoekstra and Hung (2002) when looking for an indicator that could map the impact of consumption of people on the global water resources. The concept was subsequently elaborated by Chapagain and Hoekstra (2004). The water footprint shows water demand related to consumption within a nation, while the traditional indicator of water demand (i.e. total water withdrawal for the various sectors of economy) shows water demand in relation to production within a nation. The water footprint does not only show water use within the country considered, but also the water use outside the country borders. It refers to all forms of water use that contribute to the production of goods and services consumed by the inhabitants of a certain country. The water footprint of the Dutch community for example also refers to the use of water for rice production in Thailand (insofar the rice is exported to the Netherlands for consumption over there). The water footprint also deviates from the traditional indicator of water use in that it shows not only 'blue water use' but also 'green water use'. The terms blue and green water refer to the source of the water (Falkenmark, 2003). The source of green water is rain, while the source of blue water is ground or surface water. In more precise terms, green water use in agriculture is the volume of water taken up by plants from the soil insofar it concerns soil water originating from infiltrated rainwater. Blue water use refers to the water taken up by plants from the soil insofar it concerns infiltrated irrigation water.

The idea of actively promoting the import of virtual water in water-scarce countries is based on the idea that a nation can save its domestic water resources by importing a water-intensive product rather than produce it domestically. Import of virtual water thus leads to a 'national water saving'. In addition to this, Oki and Kanae (2004) introduced the idea of a 'global water saving'. International trade can save water globally when a waterintensive commodity is traded from an area where it is produced with high water productivity (low water input per unit of output) to an area with lower water productivity (high water input per unit of output). On the other hand, of course, there can be a 'global water loss' if a water-intensive commodity is traded from an area with low to an area with high water productivity. Recent estimates of global water savings and losses as a result of international trade have been made by De Fraiture et al. (2004), Chapagain et al. (2005) and Yang et al. (2006).

Since the International Expert Meeting on Virtual Water Trade, held in Delft, the Netherlands, in December 2002 (Hoekstra, 2003) and the special session on Virtual Water Trade and Geopolitics during the Third World 
Water Forum in Japan, March 2003, the interest in the concepts of virtual water, water footprints and global water saving has strongly increased (Merrett, 2003; Allan, 2003; Wichelns, 2004; Ramirez-Vallejo and Rogers, 2004; Chapagain et al., 2005, 2006; Ma et al., 2006; Yang et al., 2006). The most comprehensive and elaborated framework for analysis available so far is offered by Chapagain and Hoekstra (2004), Chapagain et al. (2005) and Hoekstra and Chapagain (2006). In this paper we use this framework without modifications.

A nation's water footprint $\left(\mathrm{m}^{3} \mathrm{yr}^{-1}\right)$ has two components: the internal and the external water footprint. The internal water footprint $\left(W_{i}\right)$ is defined as the use of domestic water resources to produce the goods consumed by inhabitants of the country. It is the sum of the total water volume used from the domestic water resources in the national economy minus the volume of virtual water export to other countries insofar related to export of domestically produced products:

$$
W_{i}=N W U-V W E_{\text {dom }}
$$

Here, $N W U$ is the national water use and $V W E_{\text {dom }}$ the virtual water export to other countries insofar related to export of domestically produced products. In this study we only take into account water use for producing agricultural commodities. Water use for crop growth is taken equal to the evaporative water demand of the crops grown. In this way we include both effective rainfall (the portion of the total precipitation which is retained by the soil and used for crop production) and the part of irrigation water used effectively for crop production. We do not include irrigation losses, assuming that they largely return to the resource base and thus can be reused.

The external water footprint of a country $\left(W_{e}\right)$ is defined as the annual volume of water resources used in other countries to produce the goods consumed by the inhabitants of the country concerned. It is equal to the so-called virtual water import into the country minus the volume of virtual water exported to other countries as a result of re-export of imported products.

$$
W_{e}=V W I-V W E_{\text {re-export }}
$$

Both the internal and the external water footprint include the use of blue water (originating from ground and surface water) and the use of green water (soil moisture originating from rain).

International virtual water flows $\left(\mathrm{m}^{3} \mathrm{yr}^{-1}\right)$ have been calculated by multiplying commodity trade flows (ton $\left.\mathrm{yr}^{-1}\right)$ by their associated virtual water content $\left(\mathrm{m}^{3}\right.$ ton $\left.^{-1}\right)$. The commodity trade flows have been taken from the PCTAS database (Personal Computer Trade Analysis System) available from the International Trade Center (ITC, 2004). This database covers trade data from 146 reporting countries disaggregated by product and partner countries. We have carried out calculations for 285 crop products and 123 livestock products.

The virtual water content of a commodity $\left(\mathrm{m}^{3}\right.$ ton $\left.^{-1}\right)$ is defined as the volume of water required to produce the commodity in the exporting country. The virtual water content of primary crops has been calculated as the crop water requirement at field level $\left(\mathrm{m}^{3} \mathrm{ha}^{-1}\right)$ divided by the crop yield $\left(\right.$ ton $\left.\mathrm{ha}^{-1}\right)$. The crop water requirement is defined as the total water needed for evapotranspiration, from planting to harvest for a given crop in a specific climate region, when adequate soil water is maintained by rainfall and/or irrigation so that it does not limit plant growth and crop yield. Crop water requirements have been calculated per crop and per country using the methodology developed by FAO (Allen et al., 1998). 
If a primary crop is processed into a crop product (e.g. wheat processed into wheat flour), there is often a loss in weight, because only part of the primary product is used. In such a case we calculate the virtual water content of the processed product by dividing the virtual water content of the primary product by the so-called product fraction. The product fraction denotes the weight of crop product in ton obtained per ton of primary crop. If a primary crop is processed into two different products or more (e.g. soybean processed into soybean flour and soybean oil), we need to distribute the virtual water content of the primary crop to its products. We do this proportionally to the value of the crop products. If during processing there is some water use involved, the process water requirement is added to the virtual water content of the root product (the primary crop) before the total is distributed over the various root products. In summary, the virtual water content of a crop product is calculated as:

$$
V[p]=(V[r]+P W R[r]) \times \frac{v f[p]}{p f[p]}
$$

in which $V[p]$ is the virtual water content of product $p\left(\mathrm{~m}^{3} / \mathrm{ton}\right), V[r]$ the virtual water content of the root product $r\left(\mathrm{~m}^{3} /\right.$ ton $), P W R[r]$ the process water requirement when processing the root product into processed products $\left(\mathrm{m}^{3} /\right.$ ton $), p f[p]$ the product fraction and $v f[p]$ the value fraction. The latter is the ratio of the market value of the product to the aggregated market value of all the products obtained from the primary crop:

$$
v f[p]=\frac{v[p] \times p f[p]}{\sum_{p=1}^{n}(v[p] \times p f[p])}
$$

in which $v[p]$ is the market value of product $p$ (US\$/ton). The denominator is totalled over the $n$ products that originate from the primary crop. In a similar way we can calculate the virtual water content for products that result from a second or third processing step. The first step is always to obtain the virtual water content of the input (root) product and the water necessary to process it. The total of these two elements is then distributed over the various output products, based on their product fraction and value fraction.

The virtual water content of live animals has been calculated based on the virtual water content of their feed and the volumes of drinking and service water consumed during their lifetime. Eight major animal categories were included in the study: beef cattle, dairy cows, swine, sheep, goats, fowls/poultry (meat purpose), laying hens and horses. The calculation of the virtual water content of livestock products has again been based on product fractions and value fractions, following the above described methodology.

Following Chapagain et al. (2005), the national water saving $\Delta S_{n}\left(\mathrm{~m}^{3} \mathrm{yr}^{-1}\right)$ of a country $n_{i}$ as a result of trade of product $p$ has been defined as:

$$
\Delta S_{n}\left[n_{i}, p\right]=V\left[n_{i}, p\right] \times I\left[n_{i}, p\right]-V\left[n_{i}, p\right] \times E\left[n_{i}, p\right]
$$

where $V$ is the virtual water content $\left(\mathrm{m}^{3} \operatorname{ton}^{-1}\right)$ of the product $p$ in country $n_{i}, I$ the amount of product $p$ imported (ton $\mathrm{yr}^{-1}$ ) and $E$ is the amount of product exported (ton $\mathrm{yr}^{-1}$ ). Obviously, $\Delta S_{n}$ can have a negative sign, which means a net water loss instead of a saving. 
The global water saving $\Delta S_{g}\left(\mathrm{~m}^{3} \mathrm{yr}^{-1}\right)$ through the trade of a product $p$ from an exporting country $n_{e}$ to an importing country $n_{i}$, is:

$$
\Delta S_{g}\left[n_{e}, n_{i}, p\right]=T\left[n_{e}, n_{i}, p\right] \times\left(V\left[n_{i}, p\right]-V\left[n_{e}, p\right]\right)
$$

where $T$ is the amount of trade (ton $\mathrm{yr}^{-1}$ ) between the two countries. The global saving is thus obtained as the difference between the water productivities of the trading partners. 


\section{Virtual water flows and balances}

The calculations show that both Morocco and the Netherlands import more virtual water than they export, which makes them dependent on water resources elsewhere in the world (Figures 1-2).

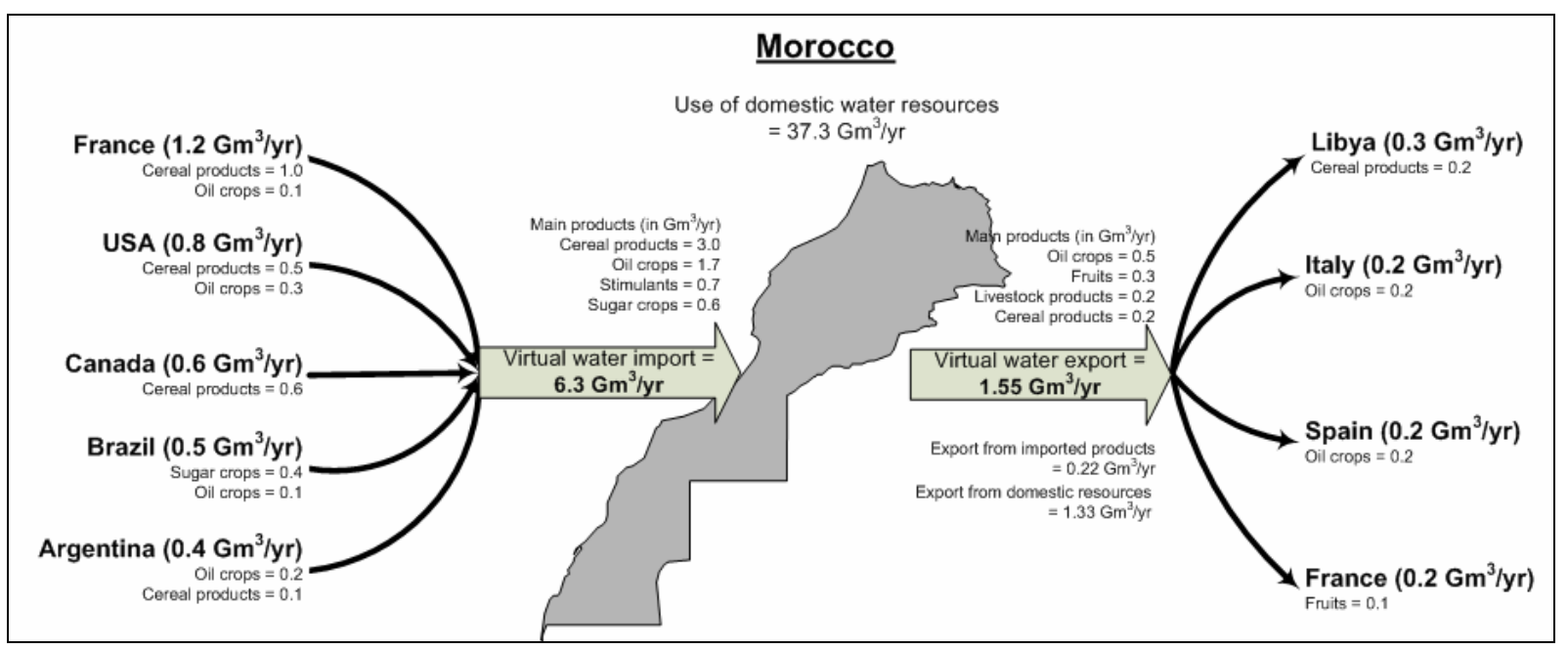

Figure 1. Virtual water balance of Morocco (insofar related to agricultural commodities).

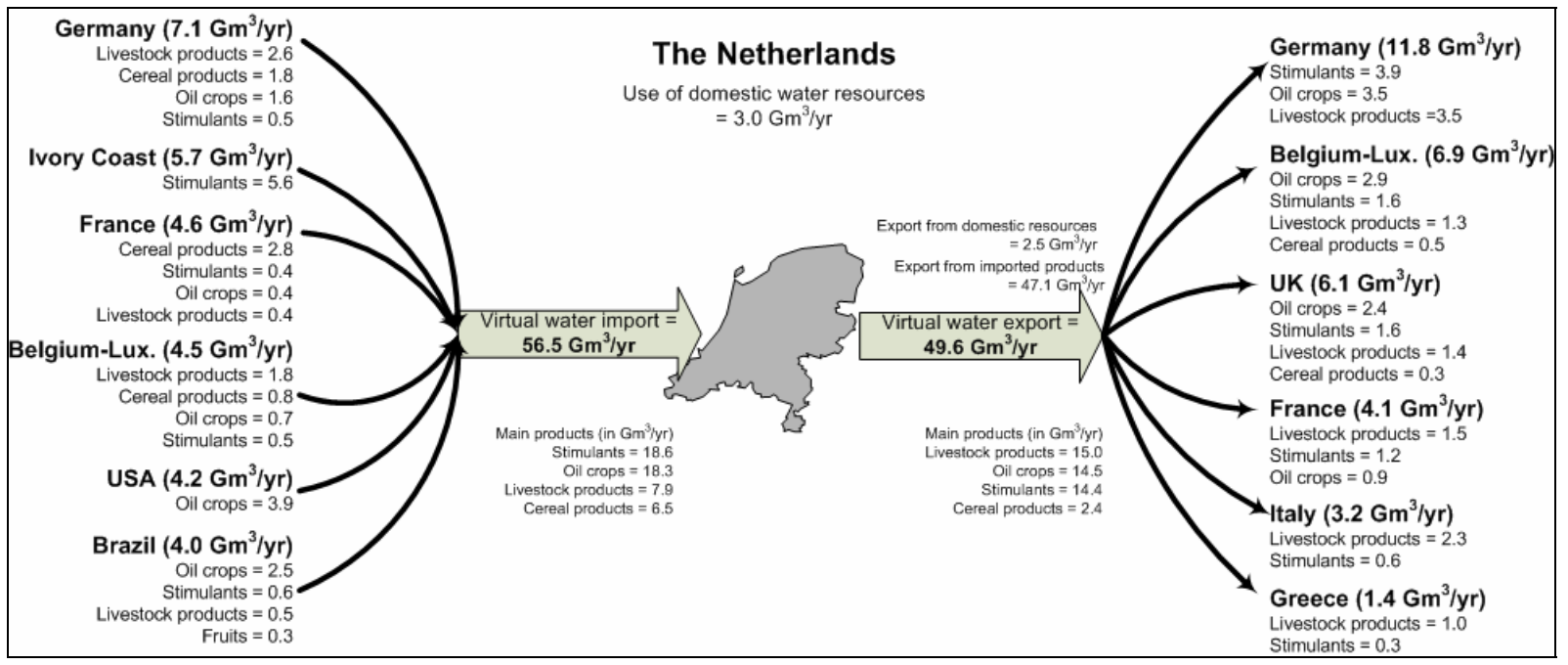

Figure 2. Virtual water balance of the Netherlands (insofar related to agricultural commodities).

In the period 1997-2001 Morocco imported 6.3 billion $\mathrm{m}^{3} / \mathrm{yr}$ of water in virtual form (in the form of agricultural commodities), while it exported 1.6 billion $\mathrm{m}^{3} / \mathrm{yr}$. In Morocco itself, water use in the agricultural sector was 37.3 billion $\mathrm{m}^{3} / \mathrm{yr}$. The import of cereals was responsible for 3.0 billion $\mathrm{m}^{3} / \mathrm{yr}$ of virtual water import. The most important sources of cereals were France, Canada and the USA. Import of oil crops was the second most import source of virtual water import into Morocco ( 1.7 billion $\mathrm{m}^{3} / \mathrm{yr}$ ). Most oil crops were imported from the USA, Argentina, the Ukraine, France, Brazil and the Netherlands. Other agricultural commodities responsible for significant virtual water import to Morocco were stimulants $\left(0.7\right.$ billion $\left.\mathrm{m}^{3} / \mathrm{yr}\right)$ and sugar $\left(0.6 \mathrm{billion}^{3} / \mathrm{yr}\right)$. 
The export of virtual water from Morocco particularly relates to the export of oil crops ( 0.54 billion $\left.\mathrm{m}^{3} / \mathrm{yr}\right)$, fruits $(0.32)$, cereals $(0.25)$ and livestock products $(0.23)$. Italy and Spain are the most important destinations of the oil crops; France and the Russian Federation are the largest customers of fruits; and Libya takes most of the cereals. About $4 \%$ of the water used in the Moroccan agricultural sector is applied for producing export products. The remainder of the water is applied for producing products that are consumed by the Moroccan population. From a water resources point of view, it seems appropriate that most of the scarcely available water in Morocco is being used for producing commodities for domestic consumption and not for export. From an economic point of view it would be worth checking whether the exported commodities yield a relatively high income of foreign currency per unit of water used (not done in this study).

In the period 1997-2001 the Netherlands imported 56.5 billion $\mathrm{m}^{3} / \mathrm{yr}$ of water in virtual form (in the form of agricultural commodities) and exported 49.6 billion $\mathrm{m}^{3} / \mathrm{yr}$. Water use in the agricultural sector in the Netherlands itself was 3.0 billion $\mathrm{m}^{3} / \mathrm{yr}$. The imports of stimulants and oil crops were responsible for respectively 18.6 and 18.3 billion $\mathrm{m}^{3} / \mathrm{yr}$ of virtual water import. The most important sources of stimulants (cocoa, coffee, tea) were Ivory Coast, Ghana, Cameroon, Nigeria, Brazil, Colombia, Kenya, Uganda and Indonesia. Oil crops came from countries such as the USA, Brazil and Argentina. Import of livestock products and cereal products were the third and fourth most import source of virtual water import into the Netherlands (7.9 and 6.5 billion $\mathrm{m}^{3} / \mathrm{yr}$ respectively). Most livestock products were imported from the neighbouring countries Germany and Belgium. Most cereals came from France and Germany. Other agricultural commodities responsible for significant virtual water import to the Netherlands were fruits $\left(1.8\right.$ billion $\left.\mathrm{m}^{3} / \mathrm{yr}\right)$ and sugar $(1.0$ billion $\mathrm{m}^{3} / \mathrm{yr}$ ).

Unlike Morocco, the Netherlands has an important through-trade, which means that much of the imports are exported again in the same or a processed form. As a result, most (about 95\%) of the virtual water exported from the Netherlands is not Dutch water, since it can be traced back to countries where the Netherlands imported from. The virtual water export from the Netherlands related to export of stimulants (not grown in the Netherlands) can for instance be traced back to countries such as Ivory Coast (cocoa) and Brazil (coffee). 


\section{Agricultural water footprints of Morocco and the Netherlands}

Morocco, with a population of 28 million people, has an agricultural water footprint of 42.1 billion $\mathrm{m}^{3} / \mathrm{yr}$, while the Netherlands, with 16 million inhabitants, has an agricultural water footprint of 9.9 billion $\mathrm{m}^{3} / \mathrm{yr}$. Both countries have a significant external water footprint (Figures 3-4). The external water footprint of Morocco is 6.1 billion $\mathrm{m}^{3} / \mathrm{yr}$. The water dependency of Morocco - its dependence on foreign water resources, defined as the ratio of the external to the total water footprint - is $14 \%$. The water self-sufficiency - defined as the ratio of the internal to the total water footprint - is thus $86 \%$. In sequence, Morocco mostly depends on virtual water import from France, the USA, Canada, Brazil and Argentina.

The total agricultural water footprint of the Netherlands falls apart in an internal footprint of $0.5 \mathrm{billion} \mathrm{m}^{3} / \mathrm{yr}$ and an external footprint of 9.4 billion $\mathrm{m}^{3} / \mathrm{yr}$. The Dutch water self-sufficiency in fulfilling the water needs for the consumption of agricultural commodities is thus $5 \%$ and the water dependency $95 \%$. In other words: the total volume of water used outside the Netherlands for producing agricultural products consumed by the Dutch is twenty times the volume of water used in the Netherlands itself. These numbers show the relevance of the water footprint concept as an alternative indicator of water demand. The agricultural water demand by the Dutch community from a production perspective is 3.0 billion $\mathrm{m}^{3} / \mathrm{yr}$ (the actual use of water in the agricultural sector in the Netherlands), while the water demand from a consumption perspective is $9.9 \mathrm{billion}^{3} / \mathrm{yr}$ (the global water footprint).

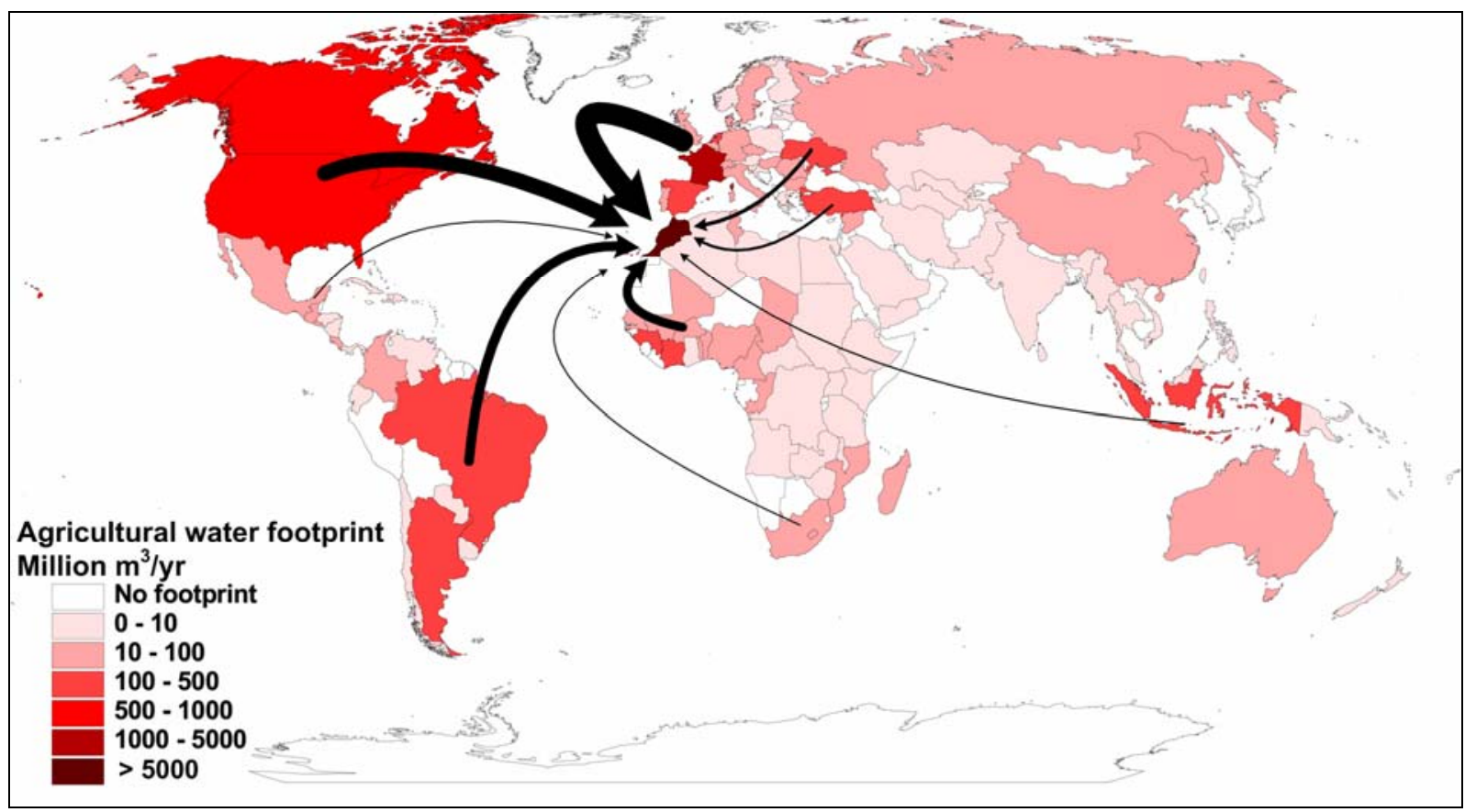

Figure 3. The global water footprint of the people in Morocco (insofar related to the consumption of agricultural products). 


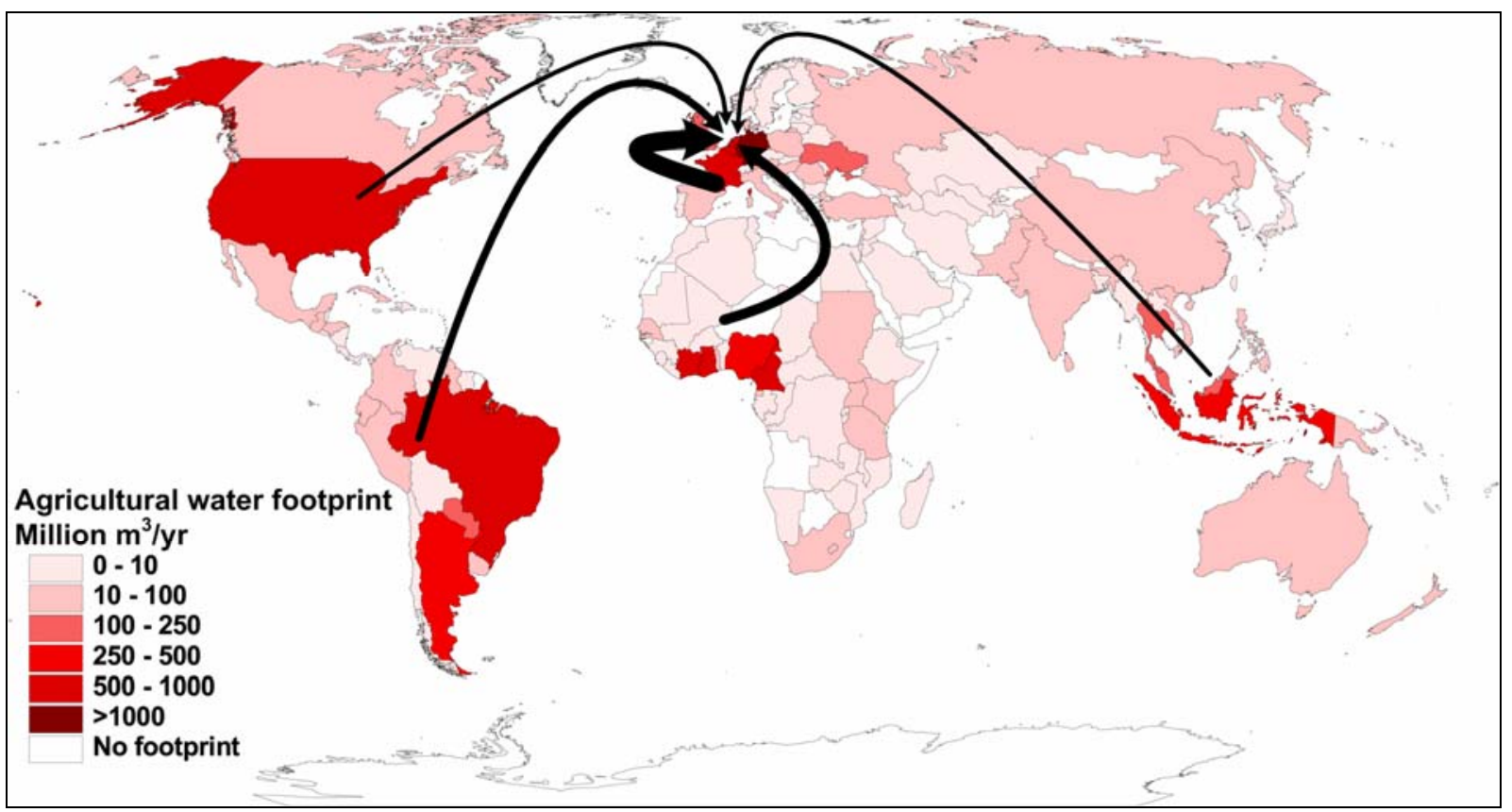

Figure 4. The global water footprint of the people in the Netherlands (insofar related to the consumption of agricultural commodities).

Morocco has an average agricultural water footprint of $1477 \mathrm{~m}^{3} / \mathrm{cap} / \mathrm{yr}$, while the Netherlands has a footprint of $617 \mathrm{~m}^{3} / \mathrm{cap} / \mathrm{yr}$. The four major factors determining the per capita water footprint of a country are: volume of consumption (related to the gross national income); consumption pattern (e.g. high versus low meat consumption); climate (growth conditions); and agricultural practice (water use efficiency). The latter two factors are unfavourable for the Moroccan water footprint. 


\section{Water savings}

Trade between the Netherlands and Morocco generates virtual water flows from the Netherlands to Morocco and vice versa (Figure 5). The net flow however goes from the Netherlands to Morocco. Morocco uses a small portion of its domestic water resources $\left(50\right.$ million $\mathrm{m}^{3} / \mathrm{yr}$ ) for producing fruits, oil crops, nuts, stimulants and sugar for export to the Netherlands. The flow of virtual water from the Netherlands to Morocco is 140 million $\mathrm{m}^{3} / \mathrm{yr}$ and is largely related to the trade of cereal products, oil crops and livestock products. It is worth mentioning here that a part of the virtual water flow from the Netherlands to Morocco does not refer to water use in the Netherlands, because some of the products traded from the Netherlands to Morocco originate from elsewhere. In those cases, the Netherlands was only an intermediate station. For example, the virtual water flow related to the trade of soybean oil crude ( 53 million $\mathrm{m}^{3} / \mathrm{yr}$ ) from the Netherlands to Morocco, can be traced back to countries such as Brazil and the USA.

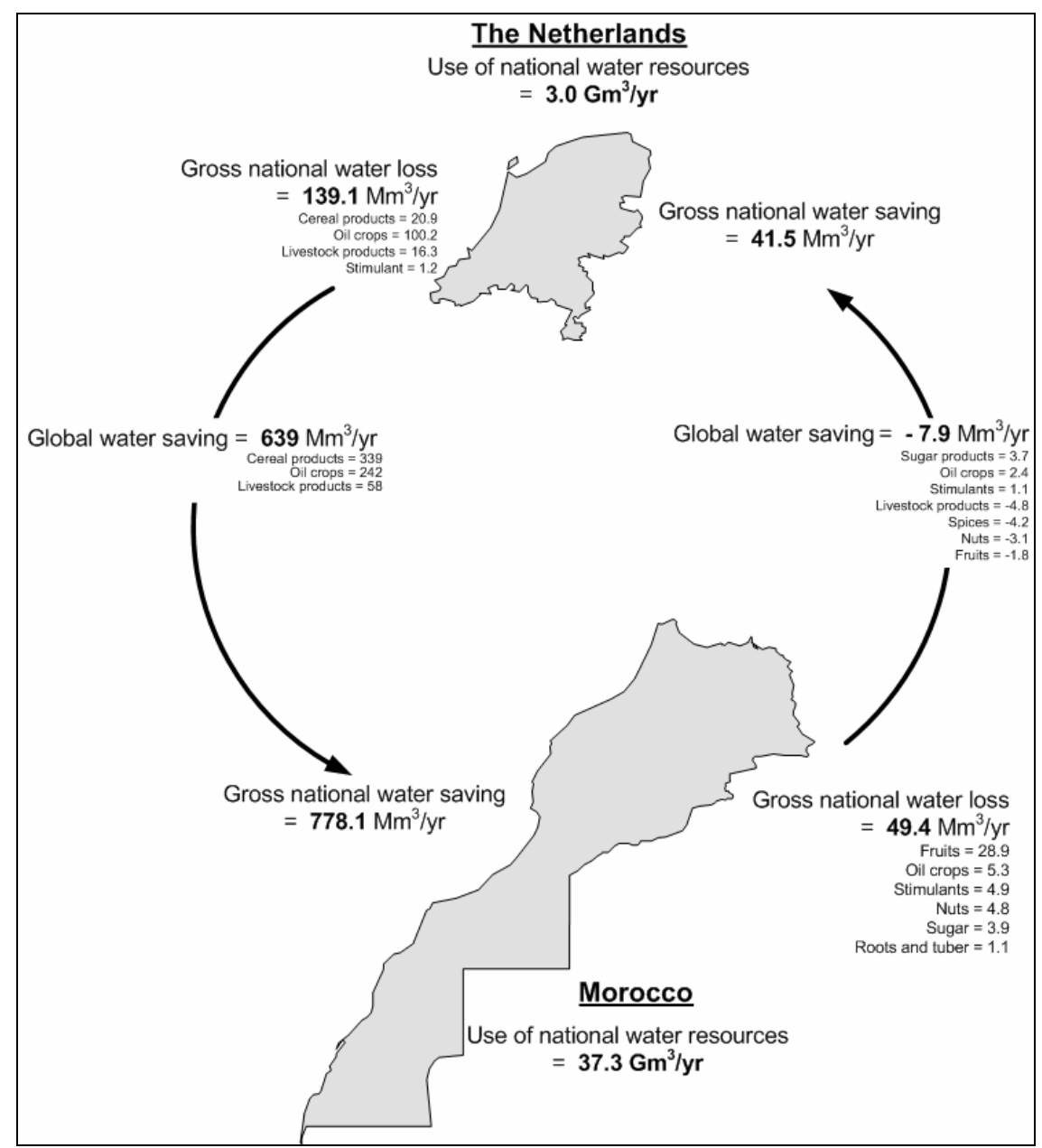

Figure 5. National water savings and losses and global water savings and losses as a result of trade of agricultural products between the Netherlands and Morocco.

If Morocco had to domestically produce the products that are now imported from the Netherlands, it would require 780 million $\mathrm{m}^{3} / \mathrm{yr}$ of its domestic water resources. Morocco thus saves this volume of water as a result of trade with the Netherlands. The fact that the products imported from the Netherlands were produced with only 
140 million $\mathrm{m}^{3} / \mathrm{yr}$ while it would have required 780 million $\mathrm{m}^{3} / \mathrm{yr}$ when produced in Morocco, means that from a global perspective - a total water volume of 640 million $\mathrm{m}^{3} / \mathrm{yr}$ was saved.

The reason for the large differences of water use per unit of product in Morocco compared to the water use per unit of imported product is twofold. One reason is that in the Moroccan climate evaporative demand is relatively high, so that, other circumstance equal, crops will consume more water than in for example more moderate climates. The second reason is that current agricultural yields in Morocco are very low (FAO, 2005). Both factors together lead to a situation where maize produced in Morocco has a virtual water content of 12600 $\mathrm{m}^{3} / \mathrm{ton}$, while maize produced in the Netherlands has a virtual water content of $410 \mathrm{~m}^{3} / \mathrm{ton}$.

If we look at the total virtual water import of Morocco $\left(6.3 \mathrm{Gm}^{3} / \mathrm{yr}\right.$, see Figure 1) the domestic water saving is much larger than the domestic water saving related to virtual water import from the Netherlands alone. According to our calculations, domestically producing the agricultural products that are currently imported to Morocco (period 1997-2001) would require $28.6 \mathrm{Gm}^{3} / \mathrm{yr}$. Thus, this is the total water volume saved in Morocco as a result of agricultural imports. The global water saving is $(28.6-6.3=) 22.3 \mathrm{Gm}^{3} / \mathrm{yr}$. 


\section{Discussion}

In this paper we show that Morocco and the Netherlands import water in virtual form, more than they export, so that in effect they both partially depend on water resources elsewhere. We also show that the agricultural trade between the Netherlands and Morocco is accompanied by a global water saving. We would like to emphasize that we present these results as an analytical fact without the intention to suggest that the virtual water flows revealed are good (e.g. because economically efficient or because saving water resources) or bad (e.g. because creating dependence or because externalising negative effects of water use without paying). The scope of this paper is not broad enough for those kinds of conclusion. Besides, we do not want to suggest that Morocco and the Netherlands import water in virtual form because they intend to save domestic water resources. Indeed, by importing virtual water they save domestic water resources, but this does not imply that the latter was an incentive for the first. International trade of agricultural commodities depends on a lot more factors than water, such as availability of land, labour, knowledge and capital, competitiveness in certain types of production, domestic subsidies, export subsidies and import taxes. As a consequence, international virtual water trade can most times not be explained on the basis of relative water abundances or shortages (Yang et al., 2003). So we fall short in explaining why the two countries have net virtual water import and in collecting grounds for judging the current trade in terms of positive and negative implications. What the paper however does show is that international agricultural trade can significantly influence domestic water demand and thus domestic water scarcity and that formulating international agricultural trade policy should therefore include an analysis of the implications in the water sector. The message is: international trade of agricultural products significantly influences the water appropriation in a country, a relation that has so far received little attention from both economists and water managers.

With increasing globalization of trade, global water interdependencies and overseas externalities are likely to increase. As visualised with the external water footprints of Morocco and the Netherlands, the consumption of imported products is connected to water use and related impacts in the countries where the products are grown and processed. For a semi-arid / arid country like Morocco, two essential political questions are: to which extent does it care about food self-sufficiency (producing the own food based on domestic water resources) and to which extent does it care about the use of domestic water resources to produce export products. Due to the limited availability of water, striving for food self-sufficiency will soon conflict with using water for producing export products. If food self-sufficiency would not be an issue, from a water-resources point of view it would make sense to stimulate export of products with a relatively high foreign currency income per unit of water used (e.g. citrus fruit, olives) and to import products that would otherwise require relatively a lot of domestic water per unit of dollar produced (e.g. cereals). 



\section{References}

Allan, J.A. (1998a) Watersheds and problemsheds: Explaining the absence of armed conflict over water in the Middle East, Middle East Review of International Affairs, 2(1): 49-51.

Allan, J.A. (1998b) Virtual water: A strategic resource, global solutions to regional deficits, Groundwater 36(4), $545-546$

Allan, J.A. (2003) Virtual water - the water, food, and trade nexus: Useful concept or misleading metaphor? Water International 28(1):106-113.

Allen, R.G., Pereira, L.S., Raes, D., and Smith, M. (1998) Crop evapotranspiration - Guidelines for computing crop water requirements - FAO Irrigation and Drainage Paper 56, FAO, Rome.

Chapagain, A.K. and Hoekstra, A.Y. (2004) 'Water footprints of nations' Value of Water Research Report Series No.16, UNESCO-IHE, Delft, The Netherlands.

Chapagain, A.K., Hoekstra, A.Y., and Savenije, H.H.G. (2005) 'Water saving through international trade of agricultural products' Hydrol. Earth Sys. Sci. Discuss. 2: 2219-2251.

Chapagain, A.K., Hoekstra, A.Y., Savenije, H.H.G. and Gautam, R. (2006) 'The water footprint of cotton consumption: An assessment of the impact of worldwide consumption of cotton products on the water resources in the cotton producing countries' Ecological Economics. In press.

De Fraiture, C., Cai, X., Amarasinghe, U., Rosegrant, M. and Molden, D. (2004) Does international cereal trade save water? The impact of virtual water trade on global water use, Comprehensive Assessment Research Report 4, IWMI, Colombo.

Falkenmark, M. (2003) Freshwater as shared between society and ecosystems: from divided approaches to integrated challenges, Phil. Trans. R. Soc. Lond. B 358: 2037-2049.

FAO (2005) FAOSTAT database, Food and Agriculture Organization, Rome.

Haddadin, M.J. (2003) Exogenous water: A conduit to globalization of water resources, In: Virtual water trade: Proceedings of the International Expert Meeting on Virtual Water Trade, edited by A.Y. Hoekstra, Value of Water Research Report Series No. 12, UNESCO-IHE, Delft, the Netherlands, pp. 159-169.

Hoekstra, A.Y. (ed.) (2003) Virtual water trade: Proceedings of the International Expert Meeting on Virtual Water Trade, Delft, The Netherlands, 12-13 December 2002, Value of Water Research Report Series No.12, UNESCO-IHE, Delft, The Netherlands.

Hoekstra, A.Y. and Chapagain, A.K. (2006) 'Water footprints of nations: water use by people as a function of their consumption pattern' Water Resources Management. In press.

Hoekstra, A.Y. and Hung, P.Q. (2002) Virtual water trade: a quantification of virtual water flows between nations in relation to international crop trade, Value of Water Research Report Series No.11, UNESCOIHE, Delft, The Netherlands.

Hoekstra, A.Y. and Hung, P.Q. (2005) 'Globalisation of water resources: International virtual water flows in relation to crop trade' Global Environmental Change 15(1): 45-56.

ITC (2004) PC-TAS version 1997-2001 in HS or SITC, CD-ROM, International Trade Centre, Geneva.

Ma, J., Hoekstra, A.Y., Wang, H., Chapagain, A.K. and Wang, D. (2006) Virtual versus real water transfers within China. Phil. Trans. R. Soc. Lond. B. 361(1469): 835-842.

Merrett, S. (2003) Virtual water and Occam's Razor, Water International 28(1):103-105. 
Oki, T., Sato, M., Kawamura, A., Miyake, M., Kanae, S. and Musiake, K. (2003) Virtual water trade to Japan and in the world, In: Virtual water trade: Proceedings of the International Expert Meeting on Virtual Water Trade, edited by A.Y. Hoekstra, Value of Water Research Report Series No. 12, UNESCO-IHE, Delft, the Netherlands, pp. 221-235.

Oki, T. and Kanae, S. (2004) Virtual water trade and world water resources, Water Science and Technology 49(7): 203-209.

Postel, S.L., Daily, G.C., and Ehrlich, P.R. (1996) Human appropriation of renewable fresh water, Science 271, 785-788.

Ramirez-Vallejo, J. and Rogers, P. (2004) Virtual water flows and trade liberalization, Water Science and Technology 49(7):25-32.

Shiklomanov, I.A. (2000) Appraisal and assessment of world water resources, Water International 25(1), 11-32.

Vörösmarty, C.J., Green, P., Salisbury, J., and Lammers, R.B. (2000) Global water resources: Vulnerability from climate change and population growth, Science 289, 284-288.

Vörösmarty, C.J. and Sahagian, D. (2000) Anthropogenic disturbance of the terrestrial water cycle, BioScience 50(9), 753-765.

Wichelns, D. (2004) The policy relevance of virtual water can be enhanced by considering comparative advantages, Agricultural Water Management 66:49-63.

Yang, H., Reichert, P., Abbaspour, K.C. and Zehnder, A. J. B. (2003) A water resources threshold and its implications for food security, In: Virtual water trade: Proceedings of the International Expert Meeting on Virtual Water Trade, edited by A.Y. Hoekstra, Value of Water Research Report Series No. 12, UNESCO-IHE, Delft, the Netherlands, pp. 111-117.

Yang, H., Wang, L., Abbaspour, K. C. and Zehnder, A. J. B. (2006) Virtual water highway: water use efficiency in global food trade, Hydrol. Earth Sys. Sci. Discuss. 3: 1-26.

Zimmer, D. and Renault, D. (2003) Virtual water in food production and global trade: Review of methodological issues and preliminary results, In: Virtual water trade: Proceedings of the International Expert Meeting on Virtual Water Trade, edited by A.Y. Hoekstra, Value of Water Research Report Series No. 12, UNESCO-IHE, Delft, the Netherlands, pp. 93-109. 


\section{Appendix: Glossary}

Virtual water content - The virtual water content of a product is the volume of water used to produce the product, measured at the place where the product was actually produced (production site specific definition). The virtual water content of a product can also be defined as the volume of water that would have been required to produce the product in the place where the product is consumed (consumption site specific definition). If not mentioned otherwise we use in this paper the production site-specific definition. The adjective 'virtual' refers to the fact that most of the water used to produce a product is in the end not contained in the product. The real water content of products is generally negligible if compared to the virtual water content.

Virtual water flow - The virtual water flow between two nations or regions is the volume of virtual water that is being transferred from one place to another as a result of product trade.

Virtual water export - The virtual water export of a country or region is the volume of virtual water associated with the export of goods or services from the country or region. It is the total volume of water required to produce the products for export.

Virtual water import - The virtual water import of a country or region is the volume of virtual water associated with the import of goods or services into the country or region. It is the total volume of water required (in the export countries) to produce the products for import. Viewed from the perspective of the importing country, this water can be seen as an additional source of water that comes on top of the domestically available water resources.

Virtual water balance - The virtual water balance of a country over a certain time period is defined as the net import of virtual water over this period, which is equal to the gross import of virtual water minus the gross export. A positive virtual water balance implies net inflow of virtual water to the country from other countries. A negative balance means net outflow of virtual water.

Water footprint - The water footprint of an individual, business or nation is defined as the total volume of fresh water that is used to produce the foods and services consumed by the individual, business or nation. A water footprint is generally expressed in terms of the volume of water use per year.

Water footprint of a nation - The water footprint of a nation is defined as the total amount of water that is used to produce the goods and services consumed by the inhabitants of the nation. The national water footprint can be assessed in two ways. The bottom-up approach is to consider the sum of all goods and services consumed multiplied with their respective virtual water content. It should be noted that the virtual water content of one particular consumption good can vary as a function of the place and conditions of production. In the top-down approach, which is used in this paper, the water footprint of a nation is calculated as the total use of domestic water resources plus the net virtual water import. 
Blue vs. green water footprint - The total water footprint of a nation or individual falls apart into two components: the blue and the green water footprint. The blue water footprint is the volume of water withdrawn from the global blue water resources (surface water and ground water) to fulfil the national or individual demand for goods and services. The green water footprint is the volume of water used from the global green water resources (water stored in soil as soil moisture) to fulfil the demand for goods and services.

Internal vs. external water footprint - The total water footprint of a country includes two components: the part of the footprint that falls inside the country (internal water footprint) and the part of the footprint that presses on other countries in the world (external water footprint). The distinction refers to the difference between the uses of domestic water resources versus the foreign water resources.

Water self-sufficiency vs. water dependency - The 'water self-sufficiency' of a nation is defined as the ratio of the internal water footprint to the total water footprint of a country or region. It denotes the national capability of supplying the water needed for the production of the domestic demand for goods and services. Self-sufficiency is $100 \%$ if all the water needed is available and indeed taken from within the own territory. Water selfsufficiency approaches zero if the demand for goods and services in a country is largely met with virtual water imports. Countries with import of virtual water depend, de facto, on the water resources available in other parts of the world. The 'virtual water import dependency' of a country or region is defined as the ratio of the external water footprint of the country or region to its total water footprint.

Water saving through trade - A nation can save its domestic water resources by importing a water-intensive product rather than produce it domestically. International trade can save water globally if a water-intensive commodity is traded from an area where it is produced with high water productivity (resulting in products with low virtual water content) to an area with lower water productivity. 

UNESCO-IHE

P.O. Box 3015

2601 DA Delft

The Netherlands

Website www.unesco-ihe.org

Phone +31152151715

University of Twente

Delft University of Technology
UNESCO-IHE

Institute for Water Education

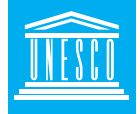

\section{University of Twente \\ The Netherlands}

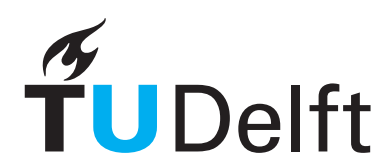

Delft University of Technology 